\title{
Béla Flerkó
}

\author{
1924-2003
}

A prominent, internationally well-known scientist and recognized pioneer in Neuroendocrinology had passed away. Béla Flerkó died on April 12, 2003.

Born and trained as an MD in Pécs, Hungary, he started his teaching and research career under the supervision of János Szentágothai at the Institute of Anatomy, Histology and Embryology of the Pécs University Medical School, and worked here till the last days of his life. As Director of this Institute for nearly three decades, he established a renowned neuroendocrine research group and a prominent laboratory, which were esteemed throughout the world.

His scientific contributions are very significant. He was the first to demonstrate the existence of estrogen- and androgen-sensitive neurons in the brain, and to show that sex steroid feedback on gonadotropin secretion is at least partly exerted via these neurons. He observed for the first time that perinatal androgen exposure decreases significantly the estrogen-binding capacity of estrogen-sensitive neurons, an effect which plays a role in the pathogenesis of androgen sterilization. He and his group were also in the forefront of scientists who localized neurons synthesizing gonadotropin-releasing hormone and other hypophysiotropic neurohormones, as well as the neural mechanism controlling follicle-stimulating hormone secretion.

Besides his excellence as a scholar, Béla Flerkó has been all his life a dedicated, outstanding university professor and teacher. He served as President (and was later honorary member) of the International Society of Neuroendocrinology, and was selected to the Editorial Board

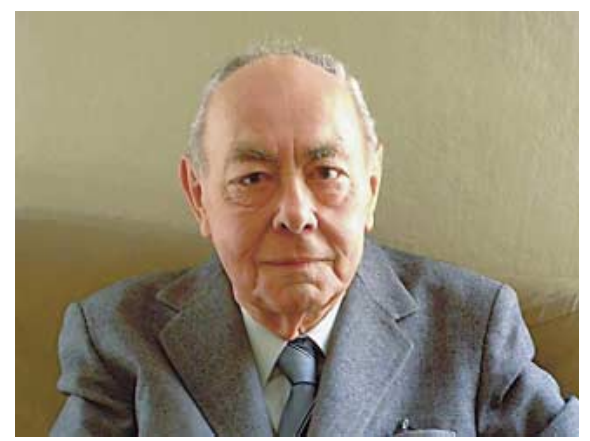

of several international journals, including Neuroendocrinology. He was also elected to the Hungarian Academy of Sciences and the Academia Europaea, and was a member of several national Endocrine Societies.

He received several awards, as the Hungarian State Prize and the Gold Medal of the Hungarian Academy of Sciences, and was chosen to deliver the fourth Geoffrey Harris Memorial Lecture. But he was above all a towering intellect, interested in music, arts, literature, a great humanist and mentor always ready to help, even when this involved political risks. And he was an unforgettable, wonderful - really a good friend.

Béla Halász

\section{KARGER}

Fax +4161306 1234

E-Mail karger@karger.ch

www.karger.com

(c) 2003 S. Karger AG, Basel

0028-3835/03/0776-0353\$19.50/0

Accessible online at:

www. karger.com/nen
} 